\title{
Why Rehabilitation and Reintegration of Offenders Are Important From a Council of Europe Perspective*
}

\author{
Ilina Taneva \\ DG I-Human Rights and Rule of Law, Council of Europe, Strasbourg, France
}

\begin{abstract}
The article presents a brief overview of the main Council of Europe (CoE) standards and principles developed in the course of the past decades and related to the European perspectives regarding the treatment of offenders, the purpose of punishment and its relation to rehabilitation and reintegration and regarding building safer societies.
\end{abstract}

Keywords: rehabilitation, reintegration, Council of Europe, community sanctions and measures

\section{Some Background History}

After the atrocities of the Second World War, the United Nations Universal Declaration of Human Rights (1948) was adopted with a view to putting on the international scene the protection of individual rights and freedoms of all persons "without distinction of any kind, such as race, colour, sex, language, religion, political or other opinion, national or social origin, property, birth or other status" (Article 2). It was supposed to be followed and further developed by binding legal instruments establishing an effective monitoring system to that effect. This process was blocked for several decades ${ }^{1}$ and Western Europe was facing a dilemma: Should the efforts be concentrated on pushing forward the universal process despite the evident difficulties at the UN level or should in parallel a regional system for human rights protection be put in place in order to bring peace and justice in Europe which had suffered the atrocities of two world wars?

The second option was chosen by the Western European political elite and thus was founded in 1949 the Council of Europe (CoE), which is today well known worldwide for its important role in the protection and promotion of human rights, the rule of law and democracy in Europe, encompassing currently 47 member States, including Russia².

Since the beginning of its existence, the safeguard of fundamental rights and freedoms of all persons in Europe (currently about 830 million of whom about 1.5 million prisoners) has been one of Council of Europe's major priority areas of action.

The European Court of Human Rights (ECtHR), established in 1959 on the basis of Article 19 of the European Convention on Human Rights (1950), can receive individual complaints from any person under the

\footnotetext{
${ }^{*}$ The opinions expressed in this article are the responsibility of the author and do not necessarily reflect the official policy of the Council of Europe.

Ilina Taneva, DG I-Human Rights and Rule of Law, Council of Europe, Strasbourg, France.

1 The International Covenant on Civil and Political Rights and the International Covenant on Economic, Social and Cultural Rights entered into force in 1976.

2 From the European States currently only Belarus (where death penalty still exists and executions are carried out) and Kosovo (not recognized by all CoE member States) are not its members. Canada, Holy See, Japan, Mexico, and the United States have an observer status with the CoE.
} 
jurisdiction of a Council of Europe member State and can deliver judgements obliging the respondent State to take action in order to put an end to human rights violations and compensate the victims.

The European Convention for the Prevention of Torture and Inhuman or Degrading Treatment or Punishment (1987) by the virtue of which was set up in 1989 a Committee bearing the same name (CPT) allows for the regular supervision of all places of detention in all member States (including penitentiary institutions).

The European Prison Rules (EPR) (first adopted in 1973 and now in their third edition of $2006^{3}$ ) set the minimum standards of treatment of prisoners and of acceptable conditions of detention.

The synergy between the ECtHR jurisprudence, the CPT work, and the EPR (and the growing number of other relevant Committee of Ministers recommendations ${ }^{4}$ ) helps advance the protection of prisoners' rights, improve prison conditions, and better prepare release and social reintegration of those detained in penitentiary institutions. The member States are guided, monitored, and assisted in implementing the standards.

\section{Punishment and Rehabilitation}

The first Committee of Ministers relevant text in this area is Resolution $[\operatorname{Rec}(65) 1]^{5}$ regarding suspended sentence, probation, and other alternatives to imprisonment, which recommends to the national authorities

to take all possible steps to ensure and extend the application of probation orders or similar measures which are of particular value in this field and have the advantage that they provide for the offender to be helped and kept under supervision during the period covered by his order, so as to encourage his rehabilitation and control his conduct. (1965, p. 2)

It further recommends to the national authorities "to consider making provision in their own legislations for other measures designed to avoid imprisonment, particularly of first offenders" (p. 3).

This approach evidences that since the very start in the centre of the Council of Europe penal policy lies rehabilitation rather than retribution and help rather than punishment, especially in the case of first-time offenders. This position also implicitly conveys the message that imprisonment should be avoided as much as practicable and penal policy should be directed to helping desistence and protecting the public by controlling and assisting offenders without cutting their social links.

This position has been maintained and further developed in the course of the following decades and is reflected in all subsequent acts, reports, or judgements emanating from the Council of Europe bodies.

The compelling position regarding the prohibition of death penalty as a pre-requisite for becoming a Council of Europe member State is another proof that protection of human life and human dignity are the cornerstone of the organization.

\section{Punishment Is Dealing With the Consequences of Crime}

It is self-evident that punishment deals with the consequences of crime and is not usually concerned with its root causes. Arguments that punishment has a dissuasive effect on other potential perpetrators are not very easy to defend as reality shows that harsher punishment does not influence crime rates or at least the link

\footnotetext{
${ }^{3}$ Recommendation (2006)2, adopted by the Committee of Ministers of the Council of Europe on 11 January 2006 at the 952 nd meeting of the Ministers' Deputies.

${ }^{4}$ Compendium of conventions, recommendations, and resolutions relating to prisons and to community sanctions and measures (http://www.coe.int/prison).

5 The CM acts addressing the governments of the member States started being called Recommendations since the 80-ties.
} 
cannot be so directly proven. The arguments that punishment installs social justice and contributes to public safety are valid if the punishment itself is just and proportionate and if it takes into account the personal circumstances of the case.

Therefore, in all relevant Council of Europe texts, the following principles are put forward and defended:

- Deprivation of liberty should be a measure of last resort and should be used for the shortest period possible;

- The punishment should be proportionate to the gravity of the offence and to the risks posed by the offender;

- The punishment should take into consideration the individual circumstances of the case;

- Retribution should not be the only or the most important aim of the punishment;

- Deprivation of liberty is a punishment in itself: All fundamental rights and freedoms of the detainee which have not been limited or taken away by the court judgement, should be respected.

- Torture, inhuman or degrading treatment or punishment is prohibited.

\section{Rehabilitation Is Dealing With the Root Causes of Crime}

It is another self-evident fact that you may not cure a problem without identifying its root causes. Dealing with crime without analyzing the reasons behind (individual, circumstantial, and societal) can at best delay future such acts and partially compensate for any negative consequences but not deal with crime effectively.

To identify root causes, one needs to assess the offender. In the centre of rehabilitation lies, the offender and not the crime committed, as the latter, although taken into consideration in the work with offenders, is not the main purpose of the action. Rehabilitation is directed towards changing the offender's behaviour and by doing so towards ensuring desistence from crime. It is a complex process and requires the joint efforts of different persons (including families and peer groups), professionals and agencies (at local and national level). There is no silver bullet for a successful rehabilitation, each individual is different, but success is dependent on the consent and consistent efforts for change on the part of the offender as well as on the continuity and professional quality of the interventions by all relevant interveners.

The major principles defended by the Council of Europe texts in relation to this are the following (this is a very schematic picture of a complex process):

- Preparation for release should start on the first day of detention;

- Individual detention plans should be agreed with each prisoner in order to prepare their release; consent is important to be sought;

- Detention should be managed in a manner facilitating reintegration into society;

- Life in prison should approximate as closely as possible the positive aspects of life in society;

- Co-operation with outside social services and as far as possible civil society should be encouraged and facilitated;

- Detainees should benefit from a rage of meaningful activities (educational, work-related, and recreational) while in prison;

- Any temporary restrictions on contacts with families and the outside world should allow at least a minimum level of contact;

- Gradual return to society should be facilitated, for example, by allowing short-term prison leaves and transfer to open prisons; 
- Through care (continuity of treatment, supervision, and care after release) is indispensable for a successful reintegration and rehabilitation;

- Social reintegration is indispensable for rehabilitation;

- Conflict resolution and restorative justice methods have their useful place in prisons.

The Council of Europe has persistently held that juveniles need a different approach and should be treated differently from adults. ${ }^{6}$ The Council of Europe is also promoting practices existing in some European countries where young adults (whose state of development is estimated by the court as not yet that of a fully-fledged adult) are often sentenced on the basis of juvenile criminal law provisions and held in juvenile detention facilities. Research shows that the physiological development of the front lobe of the brain (responsible for speech control, the expression of emotions, the ability to evaluate the consequences of one's actions, and the blocking of socially unacceptable behaviour) continues until around the age of 25 .

The institutions for juveniles need to be designed and managed differently and staffs need to have special selection and training to work with juveniles. Education is a very important part of the latter's rehabilitation process as are the contacts with their families. The small number of juveniles in detention in Europe leads often to holding them in the few existing specialized institutions far away from their families. This in turn does not facilitate their reintegration and rehabilitation process (with the exception where a specific juvenile needs to be isolated from his/her peer groups and/or families). Therefore, deprivation of liberty should be the exception and not the rule and should last for as short a period as possible. Practices existing in some European countries, to hold juveniles for observation and assessment purposes in detention only for a few months before transferring them to educational centres, should be promoted.

The Council of Europe has also developed specific rules regarding women prisoners in order to reflect the need to treat them differently from men $^{7}$. It is true that prisons are in the vast majority of the cases designed to hold adult men prisoners and that due to their small numbers in prison, women are often held in the very few existing women's prisons in a country, often far away from their families. In many cases, they are single mothers, who are losing thus their contacts with their children, with their partners and families. Women have health related and sanitary issues different from men, often a history of past violence and are more prone to depression and self-mutilation.

Another sensitive issue where the Council of Europe has consistently held the same position over the years is the treatment of persons with mental disabilities and mental disorders. According to the Council of Europe standards, such persons should not be held in a prison but in an institution specifically designed for that purpose. $^{8}$ They need special treatment and care by a professionally relevant and well-trained staff in order to help their treatment, reintegration, and rehabilitation. Such an approach also lessens considerably the strain on prison staffs who are not able or trained to deal with such persons.

\section{Rehabilitation and (Re)integration}

Some researchers consider the use of the term "rehabilitation" as having a negative "medical" connotation

\footnotetext{
${ }^{6}$ Recommendation CM/Rec (2008)11 of the Committee of Ministers to member States on the European Rules for juvenile offenders subject to sanctions or measures, adopted on 5 November 2008, at the 1040th meeting of the Ministers' Deputies.

${ }^{7}$ For example, Rule 34, EPR.

8 Rule 12, EPR.
} 
of imposing a change on a person, seen as socially inapt to live with the others, a process of forcibly "curing" a deviant person. This, according to them, puts the onus for the criminal acts on the person only who is considered to have some social deficiencies and excludes any responsibility of other factors, including the society.

Sometimes this term is replaced by "re-education" or "re-adaptation" to put a more positive sense to it.

Many researchers prefer the term "(re)integration" which is a much broader term and is seen as putting the onus not only on the offender's aptitude and desire to change but also on society, which may be on some occasions co-responsible for the deviant behaviour and which, in any event, needs to help and accept the person back into the community after release. Experts consider that true desistence can be achieved by ensuring better social integration of offenders. This involves assisting with finding employment, education, housing, community involvement, etc. (McNeil \& Schinkel, 2016).

\section{Community Sanctions and Measures}

The Council of Europe prefers using the term "community sanctions and measures" instead of "alternatives to detention". This underlines their importance as sanctions and measures in their own right and highlights that they do not involve deprivation of liberty but are executed in the community.

According to the definition contained in the relevant Council of Europe texts, the term means "sanctions and measures which maintain offenders in the community and involve some restrictions on their liberty through the imposition of conditions and/or obligations. The term designates any sanction imposed by a judicial or administrative authority, and any measure taken before or instead of a decision on a sanction, as well as ways of enforcing a sentence of imprisonment outside a prison establishment". 9

These sanctions and measures can be used at all stages of the criminal justice process: (a) at the pre-trial phase and before the sentence is final they are considered to be measures and not sanctions as guilt is not yet proven; (b) after a person is sentenced he or she can be subjected both to community sanctions as well as to community measures (like treatment measures); and (c) they can also replace a prison sentence, in which case they are considered to be its alternatives (like conditional release or replacing entirely or partially a prison sentence by electronic monitoring).

Community sanctions and measures involve using a combination of assistance and supervision methods by the implementing authorities which are intended to maintain the offender in the community and to ensure that the offender fulfils any conditions or obligations imposed by the sentence or the order. In case of breach of the conditions, the CoE texts recommend not to have an automatic recall to prison (if this is an alternative sanction or measure) but to assess the reasons for the breach and take other measures as necessary.

\section{Safer Societies}

There is often an opinion maintained by politicians and the media that the community sanctions and measures are more lenient than deprivation of liberty and that they do not serve the purpose of punishment and retribution.

As stated above, it is the Council of Europe's position that punishment and retribution should not be the primary and only purpose of a criminal sanction or measure. The public can be protected without necessarily

\footnotetext{
${ }^{9} \mathrm{CM} / \operatorname{Rec}(2010) 1$ of the Committee of Ministers to member States on the Council of Europe Probation Rules, adopted on 20 January 2010 at the 1075th meeting of the Ministers' Deputies and CM/Rec(2017)3 of the Committee of Ministers to member States on the European Rules on community sanctions and measures.
} 
depriving a person of his or her liberty and a successful reintegration into society and desistence from crime can be achieved in the community at a lower cost (economic and social for society and emotional, economic, and psychological for the offender and his or her family). De-socializing a person by depriving him or her of their liberty in order to then put additional efforts to re-socializing the same person should be reserved only for very serious, dangerous, repetitive offenders who pose a real risk to society.

Punishment and retribution are not enough to contribute to making our societies safer. Taken and used separately as a priority purpose, punishment can only contribute to the overuse of detention and to prison overcrowding which in turn often leads to inhumane and degrading treatment and may even lead to torture.

Prisons in which stress is put only on punishment and retribution help proliferate crime instead of fighting it and are damaging to prisoners and to staff members alike.

Rehabilitation and social reintegration should go hand in hand with just and proportionate punishment. The role of society in this process should be active. Media and politicians have an important role to play in this respect in shaping the public opinion and in maintaining the dialogue between the responsible agencies locally and nationally in order to pull together efforts and take effective long-term steps for dealing with crime. Crime policy is intricately linked to social, employment, educational, and healthcare policies.

\section{Conclusion}

Designing and revising crime policies is a complex and continuous process. Politicians come and go; they need to show tangible short-term results of fighting crime; the strive for efficiency and cost-effectiveness, for zero tolerance overshadows the multifaceted aspects and correlations between offending behaviour and the surrounding circumstances, between offender's risks and needs, between the quality of interventions and of the existing structures and the expected desistence from crime. On the other hand, the media and the general public tend to nurture a one-sided image of crime and a simplified view on perpetrators.

Rehabilitation, re-adaptation, and reintegration are long processes; they need time, perseverance, and investment of human and other resources.

There are sound international standards related to the treatment of offenders and to management of crime policy. There is also an outstanding amount of excellent research in the area of penology and criminology which should be better made known to professionals and should inform the actions taken by politicians. If the gap between theory, practice, and political will recedes, criminal and penal policies will impact positively the safety of our societies.

\section{References}

a. Committee of Ministers texts. Retrieved from https:/www.coe.int/en/web/cm

Compendium of conventions, recommendations and resolutions relating to prisons and community sanctions and measures. (2019). Retrieved from https://rm.coe.int/compendium-e-2018/16808ae2cf

European Prison Rules (Recommendation Rec(2006)2 of the Committee of Ministers to the member States). (2006). Retrieved from https://rm.coe.int/european-prison-rules-978-92-871-5982-3/16806ab9ae

Recommendation $\mathrm{n}^{\circ} \mathrm{R}(99) 22$ of the Committee of Ministers to the member States concerning prison overcrowding and prison population inflation. (1999). Retrieved from https://pjp-eu.coe.int/documents/3983922/6970334/CMRec+\%2899\%29+22+concerning+prison+overcrowding + and + prison + population+inflation.pdf/1d28cea8-31d2-4e2f-911c-870119b189c9 
Recommendation $\mathrm{CM} / \operatorname{Rec}(2017) 3$ of the Committee of Ministers to member States on the European Rules on community $\begin{array}{llll}\text { sanctions } \quad \text { and } & \text { (2017). } & \text { Retrieved }\end{array}$ https://search.coe.int/cm/Pages/result_details.aspx?ObjectID=0900001680700a5a

$\begin{array}{lllll}\text { White } & \text { paper } & \text { on } & \text { (2017). } & \text { Retrieved }\end{array}$ https://rm.coe.int/white-paper-on-prison-overcrowding-cm-2016-121-add3-e/16807c886b

b. Relevant case law of the European Court of Human Rights. Retrieved from https://www.echr.coe.int/Pages/home.aspx?p=home

Affaire Torreggiani et Autres c. Italie. Retrieved from http://hudoc.echr.coe.int/eng?i=001-115860

Affaire Rezmiveș et Autres c. Roumanie. Retrieved from http://hudoc.echr.coe.int/eng?i=001-173105

Case of Muršić v. Croatia. Retrieved from http://hudoc.echr.coe.int/eng?i=001-167483

Case of Ananyev and others v. Russia. Retrieved from http://hudoc.echr.coe.int/eng?i=001-108465

Case of Neshkov and others v. Bulgaria. Retrieved from http://hudoc.echr.coe.int/eng?i=001-150771

Case of Varga and others v. Hungary. Retrieved from http://hudoc.echr.coe.int/eng?i=001-152784

Case of Orchowski v. Poland. Retrieved from http://hudoc.echr.coe.int/eng?i=001-95314

Factsheet "Detention conditions and treatment of prisoners". Retrieved from https://www.echr.coe.int/Documents/FS_Detention_conditions_ENG.pdf

c. CPT reports. Retrieved from https:/www.coe.int/cpt

26th General Report of the CPT. Retrieved from https://rm.coe.int/168070af7a

27th General Report of the CPT. Retrieved from https://rm.coe.int/16807bc1cf

Living space per prisoner in prison establishments. Retrieved from https://rm.coe.int $/ 16806 \mathrm{cc} 449$

d. Council of Europe Annual Penal Statistics (SPACE I-prisons and SPACE II-community sanctions and measures). Retrieved from http://wp.unil.ch/space

e. McNeil, F., \& Marguerite, S. (2016). Prisons and desistence. Handbook on prisons. NY: Routledge. 